\section{Intersections}

Canadian Journal of Music

Revue canadienne de musique
Intersections CANADIAN TOURALL OR MUSIC

\title{
In \& Out of the Classroom: Reflections on Identity, Technology, and the Radio Project
}

\section{Charity Marsh}

Volume 26, numéro 2, 2006

In and Out of the Sound Studio

URI : https://id.erudit.org/iderudit/1013228ar

DOI : https://doi.org/10.7202/1013228ar

Aller au sommaire du numéro

Éditeur(s)

Canadian University Music Society / Société de musique des universités canadiennes

ISSN

1911-0146 (imprimé)

1918-512X (numérique)

Découvrir la revue

Citer cet article

Marsh, C. (2006). In \& Out of the Classroom: Reflections on Identity, Technology, and the Radio Project. Intersections, 26(2), 81-96. https://doi.org/10.7202/1013228ar
Résumé de l'article

Dans cet article, je partage mes réflexions concernant le projet radio, un outil pédagogique que j'ai incorporé dans mes séminaires aux études supérieures alors que j'enseignais à l'université de Regina de 2004 à 2006. Mon analyse questionne les mérites (et déceptions) du projet radio à titre d'outil pédagogique productif (et potentiellement transgressif). À partir de la pensée des théoriciens Spivak et Britzman, je réfléchis à la manière dont les liens sociaux sont modifiés par un environnement technologique extérieur à la salle de classe universitaire traditionnelle.
Copyright @ C Canadian University Music Society / Société de musique des universités canadiennes, 2007
Ce document est protégé par la loi sur le droit d'auteur. L'utilisation des services d’Érudit (y compris la reproduction) est assujettie à sa politique d'utilisation que vous pouvez consulter en ligne.

https://apropos.erudit.org/fr/usagers/politique-dutilisation/ 


\section{In \& Out of the ClassRoom: Reflections on Identity, Technology, AND the Radio Project}

\section{Charity Marsh}

\section{Preface}

The following article was initially presented at In and Out of the Sound Studio under the title, "Breaking through Sound Barriers: Embracing Community Radio as Pedagogical Practice."1 Here I reflect on the radio project, a pedagogical tool that I incorporated into my upper-level undergraduate seminars while teaching at the University of Regina from 2004 to 2006. The paper is one component of a larger ensemble of works that take up the primary themes of the conference, gender and technology, in relation to the various arts and performance practices of five women living, studying, working, and performing in Regina, Saskatchewan. At the time of the conference my fellow presenters, Jennifer Eisler, Elizabeth Curry, Katherine Binns, and Samantha Routley, were upper-level undergraduate students who had all completed one or more of my interdisciplinary Fine Arts courses.

In each of the papers, we explored questions concerning the relationships between gender, technology, and pedagogy in a cross-disciplinary context, specifically in the fields of media production, film studies, ethnomusicology, soundscape composition, and inter-media. Moreover, we called into question how normative social codes concerning gender and other signifiers are mapped onto certain artistic practices, genres, and disciplines, as well as the associated technologies. Each presenter also reflected on and theorized around personal experiences concerning such codes and how the gendering of certain technologies associated with specific artistic practices impacted their creative and learning environment. ${ }^{2}$

In naming our panel, In and Out of the Classroom: Art, Technology, and Pedagogical Practice, we attempted to provoke new thought about how certain spaces become habitually recognized as legitimate classrooms, and furthermore, how this legitimacy is embedded within a system of prescribed social norms and processes that assist in the reproduction of normative discourses surrounding art and technology in the academy. In relation to the research I presented, the title of the panel also emphasized the significance of meaning making constituted

1 Following the discussions that took place during the conference, the paper was substantially revised and presented at the IASPM-US 2006 conference in Nashville, TN, February 2006.

2 For a detailed description of each presenter's major arguments and concerns that arose during the discussion following the presentations please refer to the appendix. 
outside of the conventional classroom. Because there is a dynamic relationship between meaning making and learning, the following article addresses my argument that what occurs pedagogically in a community radio station control booth during the radio project, can be as or more productive than the pedagogical practices happening in a typical university classroom.

\section{INTRODUCTION}

Campus and community radio in Canada represents an alternative to mainstream radio; its content often consists of a diverse range of musical genres and spoken word programs, as well as opportunities to dialogue about local politics and culture. A campus or community radio station has the potential to offer marginalized voices a place from which to speak as well as an audience. It can also be an empowering site by giving people access to technology, instruction on how to use it, and the opportunity to network and foster new relations. And although there are a number of systemic issues that still need to be addressed and challenged at various levels within the organization, programming, and running of a campus or community radio station, there are a variety of possibilities for embracing campus or community radio as a productive site for thinking, learning, resistance, and transgression. ${ }^{3}$

In order to support this claim, I turn to the ongoing development of my pedagogical practice and my reflections on the radio project. The radio project is a compulsory group assignment introduced in my third and fourth year undergraduate seminar classes as one way to begin to transgress the "culturally induced technophobia" (Penley and Ross 1991) perpetuated through normative gendering practices associated with specific technologies: the microphone, the soundboard, and the control booth.

Through an engagement with Gayatri Chakravorty Spivak's theoretical work on teaching and learning, specifically, her seminal question, "what is it to learn and to unlearn?" and Deborah Britzman's psychoanalytic work on identity politics and queering pedagogy, I offer a reading of how the radio project allows for a departure from normative gendering practices associated with specific sound technologies. Furthermore, I argue that the radio project has the potential to challenge problematic power relations created in the university classroom, power relations that are often a result of social bonds formed through identity politics.

As a way to frame the discussion, I pose the following questions: What is it specifically about the radio project that creates the conditions to begin thinking through complex ideas concerning implicit and explicit relationships between gender and technology, the mediation of knowledge, how social relations and ideas of learning are formed, or the possibilities for creating and participating in new methods of learning about the self that do not rely on the self/other binary? More specifically, can the radio project help to produce new relations based on

3 For more detailed discussions of the systemic issues that need to be addressed in community radio and the possibilities for community radio as a site of resistance and empowerment for women see Waterman (2006) and Zeleke (2004). 
the concept of identification, rather than one founded on sameness and identity politics? What, if anything, about the radio project challenges how we understand identity and how social bonds are formed?

\section{MOVING FROM IDENTITY POLITICS TOWARDS IDENTIFICATION}

The concept of identity has traditionally been understood to mean a categorization based on "the sign of an identical, naturally constituted unity [...] that is, an all-inclusive sameness, seamless, without internal differentiation" (Hall 2000, 17). Cultural identity then, has been read as a "collective or true-self hiding inside the many other, more superficial or artificially imposed "selves" which a people with a shared ancestry hold in common" (17). Here identity politics is rooted in essentialist understandings of "fixed identities." Yet in his article, "Who Needs Identity?," Stuart Hall argues against such essentialist approaches to identity and instead claims identity as a "strategic" concept. For Hall, identity is strategic because identities are discursively constructed and "never unified" (17). Identity occurs through the process of identification, "a process never completed-always in process" (16). More importantly, identification "operates across difference" rather than "obliterating difference" (17). Moving away from identity politics, a politics that is bound to the notion of "fixed identities" and sameness, towards identification, "a process of articulation, a suturing, an overdetermination not a subsumption," we can begin to understand identities as "increasingly fragmented and fractured, never singular but multiply constructed across different, often intersecting and antagonistic, discourses, practices, and positions" (17).

Both Spivak and Britzman also call into question the limitations of identity politics, more specifically, within a classroom. Spivak's question "what is it to learn and to unlearn?" begins to "rethink the historicity of identity politics and the situated question of what is at stake (and for whom) when identities are at stake" (Britzman 1998, 49). For Britzman, identity politics ensnares us in a perpetual cycle of marked difference based on the existence of an understood norm. Thus, this cycle shuts down possibilities for identification. Britzman argues that identifications happen through shared historical circumstances, rather than through essential identities. As Diana Fuss' suggests, "identification is the detour through the other that defines the self" (Fuss 1995, 2).

Britzman turns to the possibilities of pedagogy in her article, "Queer Pedagogy and Its Strange Techniques," asking the following question, "Can pedagogy provoke ethical responses that can bear to refuse the normalizing terms of origin and of fundamentalism, those that refuse subjection?" (Britzman 1998, 49). Or in other words, can pedagogy persuade students (when they are backed into a corner) to give up their epistemic privilege, or their narrative authority? Britzman proposes a context where students who are unmarked give up the privileged position of the "norm" and those who are marked (as woman, queer, First Nations, "other," etc.) refuse the logic of identity politics. Yet, this is not always easy for either subject. The unmarked subject must relinquish unearned privileges granted to him (gender, class, race, ethnicity, ability) and therefore 
relinquish power, privilege, and authority. The marked subject must give up any privilege or authority granted through identity politics, no matter how small.

The question that needs to be asked here is, why? Why would the marked subject be asked to give up power? Why, if I have lived a life of oppression, should I give up the only authority that is granted to me through a collective experience because of this oppression? Why should I give up the cultural currency I gain from being an urban queer? Or the feeling of safety granted to me when attending a women-only hour at the gym? What is at stake for me? Perhaps the answer to such questions lies within the failure of identity politics and its dependence on rigid boundaries. Or maybe the answer lies in the possibilities of identification. Identification moves away from the simple concept of identifying with sameness in relation to strict identity categories towards more dynamic and complex social relations. Nevertheless, how do the processes of identification manifest in a classroom?

In her argument concerning identity politics Britzman cautions against a dependence on various methods used in education to address difference, marginalization, and exclusion. Britzman specifically takes up the liberal concept of inclusion, the introduction of "difference" as a special event, the idea that feelings are taken as the ground of self-knowledge, and the idea that experience can be used as the foundation of a collective identity $(1998,57)$. All four of these approaches fail because they presuppose a norm, maintain the problematic self/other dichotomy, and perpetuate essentialist identities. It is within these very practices that we see a commitment to "tolerance," which actually produces what Britzman refers to as the "grounds of normalization" $(1998,57)$. Moreover, this normalcy continues to produce and maintain existing power relations. But then how does one move towards a pedagogy that breaks free of such cycles of containment? How does one move away from the methods that underlie liberal democracy and navigate towards processes of identification in a classroom?

Britzman argues that the answer may be found in a pedagogy that "explores how experiences of those deemed subaltern are imagined [or by] taking a second look at the everyday normative and rethinking the normative as producing the grounds of estrangement and new forms of ignorance" $(1998,59)$. Thus, by introducing pedagogical practices which explicitly challenge what constitutes as normative, identifications are both more possible and probable. And yet the anxieties around such a queering of pedagogy may result in the de-centering of one's identity, and as Britzman argues, the de-centering of "the grounds of intelligibility upon which the self is supposed, coalesced, and recognized" $(1998,59)$. With this disruption of the familiar, there is bound to be resistance and a great deal of apprehension for all those involved. This process does not necessarily have the same effect upon the marked body as the unmarked body, but there is indeed an effect on all bodies. Britzman explains,

for those already positioned as subaltern, something different happens when listening to how one's identity gets pinned to estrangement: this has to do with not recognizing oneself in the discourses of otherness, of not living one's life as a stereotype, and of having to uncouple oneself from the regulations of stereotypes as the only condition of talk. $(1998,59)$ 
In other words, identity politics fail in that they assume too much. For instance, they assume that one's social location automatically corresponds to a particular subjectivity. A social location of subordination, vis-à-vis a racist or a sexist system, does not mean that one automatically thinks of oneself as oppressed. This is not the same thing as false consciousness, but rather it is about feeling uncomfortable with identifying oneself as a victim. How often does one feel out of place in a space of mirrored sameness? How often are identity categories illfitting? The students in my classrooms rarely fit neatly into the categories into which they are continually asked (or required) to squeeze. Nor am I suited to such contained categories with neatly drawn borders. Thus, I find the concept of identification, and its lack of a predetermined developmental path, compelling as I reflect further upon my pedagogy and the strengths and weaknesses of the radio project as a de-centering pedagogical tool.

\section{The Making of the Radio Project}

The idea of incorporating a radio project as part of my pedagogy was shaped by my research on DJ culture, the gendering of technology, critical pedagogy, and my previous experiences teaching in university classrooms. In 2002, I contributed an article on Club DJs to the Women and Music in America since 1900: Encyclopedia. In the entry, I argue that the marginalization of women DJs is based on three major factors, lack of "accessibility, promotion, and professional connections within the community" (Marsh 2002, 158). And yet, one comment that continuously surfaced in the interviews I conducted with women club DJs was that in their experience campus and community radio stations function as an accessible and transitory space; one which provides women access to technological equipment, performing experiences, and networking. The similarities in these DJs' experiences provoked me to consider how campus and community radio seems to be more accessible to those deemed Other, particularly to women. Is it simply because campus and community radio strives to be an inclusive environment? Or are there other contributing factors?

Another determining factor for the inclusion of the radio project in my seminar courses was to allow the students an opportunity to work within a new technological and social environment (equipment, audience), while offering a tangible example of theory and practice. This assignment was indeed one attempt to take up a question students consistently ask: "how does this course affect my 'real' life?" In my experience, demonstrating theoretical concepts at work in the everyday has often been a useful strategy for successfully facilitating students' understanding of complex ideas. Moreover, the radio station is also a public space where the students witness me interacting with, and performing on, different forms of technology, often not found in a university classroom environment. Proving one's technological competence often feels like a rite of passage for a professor who is read as a female. The evidence for this statement can be found in the teaching and course evaluation process. In my course evaluations, students always comment on my proficiency in running the technology despite the fact that the equipment often malfunctions or is not adequately designed for 
the needs of my courses. Thus, it is often my knowledge of the technology that comes under critique, rather than the actual equipment's failure. When discussing the matter with my colleagues, it appears that the capabilities of women who use technology in the classroom are consistently discussed, whereas the capabilities of my male colleagues who use similar equipment are not addressed in the evaluations. On a weekly basis, the production of the radio show and my presence on the mixing board and behind the microphone became an important signifier of my technological competence.

My disenchantment with the understanding of the conventional classroom as the most appropriate, productive, and legitimate learning environment, is another reason for developing the radio project as part of my teaching practice. In my teaching methodology I constantly seek out new methods for repositioning the discussions that occur inside the academic classroom outside into the local community, thus enabling a creative shift in how students think about their relationship to learning and to their surrounding community. By moving outside of the conventional classroom, I believe it is possible to break through the invisible walls that act as a container for knowledge production and educational practices.

The life narratives of my students, as well as the complicated issues surrounding identity, which play a critical role in social relations in Regina, Saskatchewan also factored into my decision to create the radio project. Following my first semester of teaching at University of Regina, I realized that the way identity politics figured prominently in the classroom was somewhat different from my previous experiences when teaching at Trent University and York University. In my classes, there were diverse students, with different life experiences, yet there seemed to be strict boundaries drawn around students who identified as Aboriginal and those who identified as non-Aboriginal (read White). These strict boundaries are represented outside of the academy in highly visible ways in the city, the province, and generally across the prairies in a fashion quite different from the rest of Canada. The divide occurs physically on the main campus of the University of Regina, which includes First Nations University of Canada. A road separates First Nations University of Canada from the rest of the institution. Although the relations between Aboriginal and non-Aboriginal peoples are complicated by a violent history of colonization, suspiciously it is the Aboriginal students at First Nations University of Canada and the University of Regina who are often asked to cross the divisive lines in order to fulfill requirements of their degrees. ${ }^{4}$ The result is indeed productive in that the classroom becomes a potential space for dialogue and new relations, but often identity politics play a role in maintaining a divide. With the radio project I hoped that by re-situating the place of learning into an alternative space, new relations founded on processes of identification might flourish.

4 Anywhere from $35 \%$ to $50 \%$ of the students in my upper-level undergraduate Fine Arts courses identified as First Nations or Métis. Most of these students are from the Department of Indian Fine Arts at First Nations University of Canada. 
Prior to introducing the parameters and content for the radio project to the students, I present lectures on the history of radio, the evolution of radio and broadcasting technologies, and the concept of mediation. The presentation of these lectures and the contextual significance depends on the nature of the course being taught. ${ }^{5}$ The radio project consists of six steps. Initially the students are asked to organize themselves into groups of three by choosing a focus or theme from the outline. In the Popular Music course the list includes examples such as "Identity and Nation," "Representation of Music Icons," and a community-based project titled, "Prairie Roots Hip-Hop Project." In the Arts and Everyday Life class, the choices range from "Cultural Resistance: DIY Culture," to "Bodily Provocations," and "Superheroes." Each week of the semester is assigned a theme and a specific date for broadcasting. Students are given the opportunity to choose their own groups for the project, but the pre-determined circumstances most often do not allow for a group to consist entirely of already established friends. However, when I created the assignment this was not my underlying motive. As will become evident in my analysis groups being determined by the weekly themes proved to be an important factor for the success of the project.

After the groups are formed, the students are asked to read the required articles for the specific theme, outline the key ideas, concepts, and arguments, make the decision about which of these should be included in the radio show, and then engage critically with these ideas in order to formulate interesting and thoughtful content. The groups are then required to prepare a one-hour spokenword program around their chosen theme to be broadcast live during the show's weekly time slot. Throughout the process, the students are required to meet with me at least twice to discuss the lecture and reading material, the concepts, the themes, "appropriate" examples, the format of the show, their excitement, fears, and anxieties. ${ }^{6}$ On the day of the broadcast, I demonstrate the various technological components of the space to the students in the hour before the show, and then we go live to air. Throughout each broadcast, I act as producer and host, following through on my commitment to assist with the discussion if needed. ${ }^{7}$

5 Over the course of two years I included the radio project in the following courses at University of Regina: Fine Arts 300-AG Art and Technology in the 20th and 21st Centuries, MU 320 AG Themes in Popular Music, MU 112/MU 480 World Music, and FA 200 Arts and Everyday Life.

6 Because the show aired from $11 \mathrm{am}$ to $12 \mathrm{pm}$, there were some content restrictions. For example, language and lyrical content were restricted. On one show, the students were discussing essentialist ideas concerning gender and popular music. During the show the categories of "teeny-bop" and "cock-rock" were taken up critically. Following the broadcast, the station manager reprimanded me for allowing the students to use the term "cock-rock" on air. In the same conversation however, he thanked me for playing Scorpion's "Rock You Like a Hurricane," (an example of the "cock-rock" genre), as he was a huge fan of the band. Ironically, we were being censored for using language deemed inappropriate, even though we were problematizing the term, and yet, we were being praised for playing a musical example that adopts metaphors of violence ('I'm gonna' rock you like a hurricane"), as a way to express male heterosexual desires.

This commitment, which was included in the guidelines for the assignment, seemed to calm some of the students' anxieties. It also confirmed my investment in their show, as well as my commitment to the objective learning outcomes. 
Following the program, I ask each group to listen to their show (re-broadcast the next day), and write critical response papers to the entire process, addressing their choice of theme, their preparation, the time in the control booth, how they thought it turned out, listening to the re-broadcast, and thoughts on their colleagues' shows. Once the course is finished and their final grades submitted, I invite the students to voluntarily return a copy of their response to me so that I may revise the assignment according to its strengths and weaknesses, reflect on my pedagogical practice, and write about the assignment. ${ }^{8}$ The students' responses have enriched the development of my pedagogical practice and have provoked me to analyze the radio project, and more generally, campus and community radio, as a potential site for meaning making through processes of identification.

\section{The Radio Project: What Does it All Mean?}

In their reflections on the radio project, University of Regina students raise a number of issues about the process, their anxieties, and for some, the sense of accomplishment at the conclusion of their broadcast. ${ }^{9}$ Initially, most of the students oscillated between excitement and apprehension due in part to the unfamiliarity of the new space, the new technology, the potential audience outside of their peers, the sense of responsibility that accompanied the position of having to share their "newly acquired" knowledge, and the sense of urgency inherent in live broadcasting. Because the community radio station in Regina is not affiliated with the university, the radio project took us off campus to a downtown location. Not only was the geographical location new to the students, but the actual space inside the radio station, in the control booth, and on air, was outside the familiar territory of their classroom.

The technologies involved in the preparation of the programming (for example, finding examples to assist when making their arguments and formatting these according to the station's technological equipment) and broadcasting often caused an intense emotional response for the students. The primary apparatus that mediated these emotions seemed to revolve around each individual's relationship to the microphone. The sense of performativity one may have from speaking into or performing in front of a microphone played an essential role in how each body related to the space. In all of the groups the comfort level of the participants ranged broadly, and the microphone seemed to intensify the stakes. However, my ease with the microphone, the control board, and the computer (based on prior experience and performing each week) also played a critical role in the creation of a somewhat calmer atmosphere. In many instances, I purposefully performed an introduction to the show in a manner that the stu-

8 At the University of Regina, $90 \%$ of my students participated and returned a copy of their response to me, on the understanding that I might include some of their comments in my research and writing about the radio project.

Students who chose to participate in my research were assured that their identities would remain confidential; their comments would be represented using pseudonyms or "student" in order to protect their anonymity, however, other signifiers of identity, such as gender, would be revealed for the purpose of the analysis. 
dents found reminiscent of favourite historical DJ personalities. The students recognized many of these personalities from popular culture references or from seminar discussions. This technique generated a sense of play that often relieved initial tensions and stage fright.

Another issue that arose during the project was the constitution of the listening audience and the fact that, outside of their peers who were required to listen, the audience remained nameless. A number of questions concerning the audience became significant for the students and myself while reflecting on the project. Who in the community was listening? What did the audience think of the content that was being broadcast? Did the audience call into the station? Would folks who knew the students listen and discuss the show with them? Because the programme was being broadcast into the community, there was a new emphasis on the students' responsibility for the show's content. There is an anxiety that accompanies being positioned as a conveyor of knowledge, which is quite different from the anxiety that is associated with being the receiver of knowledge. Alongside this anxiety is a sense of urgency that does not surface in the conventional classroom. Generally, in the classroom a student is given time to think and formulate a response to a question or a discussion, whereas on the radio "dead air" is simply not permitted. Urgency in this context both frightened and motivated the students.

On my first reading of the students' responses, I found their views of the project insightful, but somewhat disheartening as their writing indicated what I initially understood to be stereotypical normative gender patterns. At first glance, I realized that the responses from the men in the class spoke specifically to their enjoyment of a project that allowed them a space in which to demonstrate their technological skills, as well as their command of the content and theoretical material. One student claimed the radio project gave him "the chance to show off his stuff, especially how theory and practice come together." Another male student pointed out that the project "allowed me to demonstrate the critical skills I was getting out of the course and share these in a different format publicly." The majority of the responses from the men in the classes contained an excitement around the public aspects of the radio project, the importance of demonstrating their mastery of the content, and the excitement of having a substantially larger audience.

In contrast, the women's comments tended to focus on their anxieties about how the community audience would receive them. One student expressed her concerns with the unknown stating, "I find it intimidating to think about who might be listening [...] I don't get to witness or be part of their experience of listening to me. This makes me uncomfortable." Another student addressed how she embodied the project and the subsequent effects:

Initially, I was quite stressed over the whole prospect of doing a radio show. I have never been on the radio before ... When it came time for the show, I was so nervous. So horribly nervous. I knew that the listeners couldn't see me, so it didn't really matter-but still, my inner butterflies were making me sick. It didn't get better ... I remained nervous throughout the whole show and stuttered a lot. I blurted out things and cut people off. In my head, I 
didn't think we'd make it the full hour ... I tried and tried to figure out what we would say next. Then it was over. I still remained nervous for another 5 minutes. Charity said we did well. So did my partner...but I think those are just things people say...I really don't think it went that well.

Not only is the unknown disturbing for this student, but her lack of confidence in the performance and her mistrust in the feedback given to her suggests other more normative gendered responses in relation to technology and public space. ${ }^{10}$

Nevertheless, these were only my initial impressions, my first glance through their responses. At this point in my analysis, I found it essential for me to seriously re-consider my reading practices, and the degree to which they are shaped by the discourse surrounding identity politics. A more sophisticated analysis of their responses might actually demonstrate the complex social relations resulting from the project, relations that did not fit so neatly into the categories that I initially read. Subsequently, upon a more careful reading, the students actually articulated something else. I could see that many of the students were addressing a new discomfort, an unsettling that they were attempting to negotiate by using familiar language.

As these female students continued to reflect on the project, I discerned a shift away from gender stereotypes associated with taking up public space, to a more complex way of thinking about the process and its results. One woman notes,

While I enjoyed the new experience of radio, it is not something I could consider myself getting into later on in life. While I am in journalism, I hate radio broadcasting of any kind...I'm much more of a print type myself. However, new experiences are essential to the well-being of our selves, and so I regret nothing despite how much I despise hearing my voice recorded!

Another female student claims,

I feel that I talked entirely too much. This would not be so bad if the points I made were intelligible. I would like to state for the record that they were intelligent and well thought out in my own mind, and I understood everything I was going to say before I said it, but once I began to talk, my train of thought disappeared. And I blame it on the fact that I was not in character, but rather I was representing myself, my own ideas.

From these comments, it is obvious that the students are attempting to understand their relationship to the project itself. In their language the gender norms do not necessarily disappear but they are more nuanced. Thus, when one student claims the radio project helped to provide her with a sense of belonging and validation-"I really enjoyed the new methods of learning, the interdisciplinary approach. I really felt, that although it often seems I'm straddling disciplines,

${ }^{10}$ These normative responses have been linked to systemic barriers previously mentioned-lack of accessibility, promotion, and professional connections within the community-as well as "security, harassment, technophobia, a 'hipster' environment, and a boys club environment" (Zeleke in Waterman 2006, 79). 
I was validated"-her need for validation may cause concern, but her engagement with a new methodology of learning that provides her with something she needs is also productive. How students position themselves and their performance in relation to other aspects of their lives speaks to the unfamiliarity of the circumstances and the need to situate their experience in relation to something familiar. Sometimes the familiar is tied to essentialist ideas of knowing and being.

As I have previously argued, the radio project positioned students outside of the conventional classroom, prompting them to engage with the theory taught in the classroom actively through their own practices. This technique proved useful, as the following comments show: "Doing this project really gave us a chance to let what we learnt this semester sink in"; "I enjoyed the project, because we got to apply ideas we were learning which rocked because it helped me better understand what we were talking about"; and "The radio show ... makes us apply what we learned and asks us to challenge ideas and beliefs that are often pressed on us." In fact, for some students the radio project provoked completely unexpected reactions:

I can definitely say that the radio project is unlike any other group project that I have participated in. This project truly pushed my limits in what I would normally do. [...] I was very nervous and unsure about the project throughout the entire semester even until the very last minute that we were on air. I'm glad that I participated though because it was a huge learning experience and I gained a lot of knowledge from the whole process. It was really great to see how things were actually done. I mean usually you're just the audience. You're just listening. You usually don't get the chance to see how things are produced and done on air.

In creating something tangible-a radio show-and broadcasting live to air into their local community, students were invited to become active participants in a way that they had never been asked before.

Some of the participants argued that the assignment opens up possibilities for understanding the course material. One student noted, "The radio assignment gave us a chance to experience something practical and it gave us the chance to study ideas and concepts through discussions and conversations that we were responsible for ourselves." Identifying responsibility as an integral component of the project also suggests that through the process, the students become aware of the responsibility and power involved in conveying knowledge. One student discussed the importance of being responsible to the community: "It was really interesting to think of addressing issues of 'academic language' by having to make the ideas accessible [to the community]. I even thought about how you, as the professor, were sharing some of your authority as teacher with us. Or giving it up, or I don't know." A shared sense of responsibility for themselves, their colleagues, and the community, pointed towards an increased sense of identification among students.

If, as Britzman argues, identifications occur because of circumstances that people share rather than essential identities, then the radio project may be con- 
sidered a success. The identifications that began to take place throughout the project completely altered the dynamics of the classes. As I previously noted, the tendency in my classes was towards identity politics. The relations were primarily based on sameness of marked signifiers: gender, race, ethnicity, age. Many of these relationships were complicated by disciplinary affiliations within the Faculty of Fine Arts (also implicated in essentializing normative associations), and the differentiation between those students from the University of Regina and those students affiliated with First Nations University of Canada. Moreover, the gendered responses to technology also played a role in class dynamics.

Following the radio project, students began to identify with each other because of a shared sense of responsibility, as well as the strangeness fostered by technologies found within the space (i.e. the microphone, their bodily fears, their excitement). Rather than bonding through essential qualities of sameness (Whiteness, Native-ness, gender), the students identified with each other because of shared anxieties, excitements, and responsibilities. Gendered relations to technology shifted somewhat, as all students were required to participate with unfamiliar technologies in groups of three under the direction of their female professor in an unfamiliar environment outside of the conventional classroom.

Thus, to address the question, "what about the radio project challenges how we understand identity?" we must reflect on how the radio project allows us to venture outside liberal strategies that often ensnare us in the conventional classroom. The radio project opens up new discursive possibilities for identification that lead to greater reflexivity among students. The radio project challenges the students to contemplate how essentialist identities are ingrained, and how difficult it is to think beyond them. Furthermore, the radio project demonstrated that identities actually "emerge within the play of specific modalities of power, and thus are more the product of the marking of difference and exclusion, than they are the sign of an identical, naturally constituted unity" (Hall 2000, 17). In the students' reflections there is evidence of a growth in understanding, an understanding that came out of their participation in the radio project. And yet while the radio project opened up new spaces for identification and altered the dynamics of these specific classrooms, I am not so naïve as to suggest that the project eradicated all performances of identity politics.

\section{Contemplating My Approach: An Ethical Response}

As both a teacher and researcher of theory and practice in a university environment, I understand the responsibility to contemplate the epistemological implications of pedagogical practices that I draw on both in- and out-side of the conventional classroom. In order to create a productive teaching and learning environment, I realize how essential it is to reflect on pedagogy and how students respond to different methodologies, as well as the importance of being willing and able to revise and make changes according to the learning needs of the students. Similar to the shifting dynamics found within a group of students in a classroom, my pedagogical practices are not static, nor should they be static. Each classroom contains various networks of social relations and allegiances 
drawn around experiences of sameness or difference. These factions are often complicated further by a wide range of identities, learning dis/abilities, varying degrees of interest in the subject material, as well as the surrounding political, social, geographical, and cultural context within which the academic institution is located.

Learning is fraught with conflict; at times learning can be incredibly painful. I acknowledge that I, as a facilitator of knowledge in and out of the classroom, am also implicated in this process of unease and discomfort. Through continual reflections on my own pedagogical practices, I have come to view the radio project as a tool that momentarily unsettles and challenges both the students and myself in many ways. The radio project has the potential to become a practice of queering pedagogy that makes possible a momentary breaking point from a system that is embedded in a liberal discourse of identity politics. However, I must make it clear that I also realize the paradox of attempting to work within a process of identification rather than one of identity politics. Identity is constituted through discourse and through identifications. Indeed Stuart Hall writes, "its object is as likely to be the one that is hated as the one that is adored" $(2000,3)$.

It is critical to move outside of the fixed boundaries of identity politics towards identifications that allow us to think about how identity needs an Other to hold meaning, and that identity is constituted through the discourses available within any given social and historical moment. "So even when the course material has gestured to difference [including different ways of reading space], and moving outside of the conventional classroom there still remains the question of how difference is to be read" (Britzman 1998) or against what difference is to be read.

I have argued that the classroom itself embodies the components for fostering community, a community that is not necessarily established because of a shared identity, but rather a community founded on identifications which are engendered through a specific pedagogical practice. What does this mean in relation to Spivak's question "what is it to learn and to unlearn?" or Britzman's queer pedagogy, or the classroom as a highly politicized space? For me the significance is found in the knowledge that new experiences, new relations, new ways of being in the world exist and that perhaps that which we cling to-familiarity-is not always the most productive way to disrupt power relations. It is essential that we engage in the practice of "unlearning" despite the anxieties that this may cause. What we understand as strange may hold more possibilities. Furthermore, the radio project has enabled these particular groups of students and myself to produce learning environments that, at times, decentre relations of power, resist codified gender norms, and re-interpret the possibilities for identifications.

\section{REFERENCES}

Britzman, Deborah. 1998. "Queer Pedagogy and Its Strange Techniques." In Inside the Academy \& Out, ed. Janice Ristock and Catherine Taylor, 49-71. Toronto: University of Toronto Press. 
Doane, Mary Ann. 2000. “Technophilia: Technology, Representation, and the Feminine." In The Gendered Cyborg: A Reader, ed. Gill Kirkup, et al, 110121. London and New York: Routledge.

Fuss, Diana. 1995. Identification Papers. New York and London: Routledge.

Hall, Stuart. 2000. "Who Needs 'Identity'?" In Identity: A Reader, eds. Paul du Gay, et al, 15-30. London: Sage Publications.

Haraway, Donna. 1991. "A Cyborg Manifesto: Science, Technology, and Socialist-Feminism in the Late Twentieth Century." In Simians, Cyborgs, and Women: The Reinvention of Nature. 149-182. New York: Routledge.

Marsh, Charity. 2002. "DJ, Club." In Women and Music in America Since 1900, ed. Kristine H. Burns. 158-159. Connecticut and London: Greenwood Press.

Marsh, Charity and Melissa West. "The Politics of Academic Fandom." Forthcoming in Studies in Music. London: University of Western Ontario Press.

McCartney, Andra. 2000. "Cyborg Experiences: Contradictions and Tensions of Technology, Nature, and the Body in Hildegard Westerkamp's 'Breathing Room."' In Music and Gender, eds. Pirkko Moisala and Beverley Diamond. 317-335. Urbana and Chicago: University of Illinois Press.

Pegley, K. and Virginia Caputo. 1994. "Growing Up Female(s): Retrospective Thoughts on Musical Preferences and Meanings." In Queering the Pitch: The New Gay and Lesbian Musicology, eds. Philip Brett, Elizabeth Wood, and Gary C. Thomas. 297-314. New York: Routledge.

Penley, Constance and Andrew Ross. 1991. Technoculture. Minneapolis: University of Minnesota Press.

Spivak, Gayatri. 1993. Outside in the Teaching Machine. New York and London: Routledge.

Théberge, Paul. 1997. Any Sound You Can Imagine: Making Music/Consuming Technology. Hanover and London: Wesleyan Press.

Waterman, Ellen. 2006. "Purposeful Play: Women Radio Artists in Canadian Campus and Community Radio." In Atlantis 30.2. 76-87.

Wise, Sue. 1984. "Sexing Elvis." In Women's Studies International Forum, Vol. 7, No. 1, 13-17.

Zeleke, E.C. 2004. The Status of Women in Community-based Radio in Canada. $<$ http://www.ncra.ca/women/stratPlan.cfm>. 


\section{APPENDIX}

\section{In AND OUt of the Classroom:}

\section{Art, Technology, and Pedagogical Practice-A Summary}

\section{Jennifer Eisler discussed Regina's Community Radio Station 91.3 FM CJTR} in her paper, "Musical Transmissions 2005: Reflections of a Community Radio Programmer." She was one of only three women out of the one hundred or so music programmers. Eisler noted, however, that a significant number of women programmers host talk shows. The differentiation speaks to the gendering of space and the all too familiar binary of public/private, as well as to conventional ideas around the sharing of musical knowledge and expertise. During the question period that followed Eisler's paper, a number of issues were discussed concerning the gendering practices associated with record collection, ${ }^{11}$ fandom, ${ }^{12}$ and performance technology. ${ }^{13}$

In "Chain Reaction 2005: Reflections on Concept and Sound Process," Katherine Binns and Elizabeth Curry spoke about their experiences creating an inter-media piece comprised of video and sound through a collaborative process wherein each artist responded to fragments of either the image or the sound created by the other. One of the key theoretical ideas they attempted to address in their work is the issue of authorship. Through an analysis of their artistic process in video and sound, Binns and Curry identified some of the issues that arise when attempting to create in collaboration using unconventional methods. For example, the two artists did not interpret each other's work in the same way, which led to multiplicity of meaning in their artwork from its inception. Their collaborative process also demands more of the audience and subsequently provokes a multi-layered reading. At the conclusion of their presentation Binns and Curry discussed how university classes maintain and closely guard the status quo through devices such as the use of male-dominated canons, the emphasis on Western European traditions, and the discouragement of alternative methods for creating art works, particularly the type of collaboration they practiced.

To begin her presentation, "Parfait 2005: Embracing Technology and Becoming Machine," Samantha Routley screened her experimental film Parfait, which depicts the process of maternal reproduction and growth that is subsequently penetrated by machinery. The machinery symbolizes the technologies of society, the portrayal of women, female stereotypes, and technologies of consumption. Throughout the short film, the female figure continues to be over taken by the machinery until she herself embodies what Huyssen refers to as "the ultimate technological fantasy," or the potential for "creation without

\footnotetext{
${ }^{13}$ For further reading on performance and technology refer to McCartney (2000); Théberge
} West.

${ }_{11}^{11}$ For further reading on collection practices refer to Straw (1997).

${ }_{12}$ For further reading on fandom refer to Pegley and Caputo (1994); Wise (1984); Marsh and (1997). 
the mother" (Doane 2000, 114). For Routley, who draws on the work of Haraway and Doane, there is both a possibility and a danger to address when contemplating the relationship between women and technology. Moreover, certain technologies and processes become encoded with meaning based on normative gender roles. Routley spoke to the significance of how technology is designed and understood within her own discipline-media studies and production. She explained her conscious decision to use the genre of experimental film for the work in order to call into question the gendering of specific film genres as feminine or masculine.

\section{ABstract}

In this article I share my reflections on the radio project, a pedagogical tool that I incorporated in my upper-level seminars while teaching at University of Regina from 2004 to 2006. My analysis interrogates the merits (and disappointments) of the radio project as a productive (and potentially transgressive) pedagogical tool. I draw on theorists Spivak and Britzman in order to think about how social bonds are mediated by a technological environment outside the conventional university classroom. Furthermore, I explore how, through alternative pedagogies such as the radio project, social bonds may develop through processes of identification rather than identity politics.

\section{RÉSUMÉ}

Dans cet article, je partage mes réflexions concernant le projet radio, un outil pédagogique que jai incorporé dans mes séminaires aux études supérieures alors que jenseignais à l'université de Regina de 2004 à 2006. Mon analyse questionne les mérites (et déceptions) du projet radio à titre doutil pédagogique productif (et potentiellement transgressif). À partir de la pensée des théoriciens Spivak et Britzman, je réfléchis à la manière dont les liens sociaux sont modifiés par un environnement technologique extérieur à la salle de classe universitaire traditionnelle. 